\title{
Defensive Measures Adopted by Czechoslovak Authorities in Reaction to Danger Posed by Nazi Germany during Years 1935-1937
}

\author{
doc. PhDr. Soňa GABZDILOVÁ, CSc. \\ doc. Mgr. Milan OLEJNÍK, PhD
}

\begin{abstract}
Submitted paper is mapping measures enacted by Czechoslovak government during period of years 1934-1937 as a reaction to aggressive policy of Nazi Germany. Attention is given to proceedings aimed at increase of fighting ability of CzechoslovakArmy such as field military exercises improvement of organization structure and elaboration of defensive operations in response to possible German attack. Focus is placed on defense construction works protecting boundaries, namely along western region of state. The paper is endeavoring to provide, in a concise fashion, a picture of struggle of Czechoslovak political leaders and military to prepare CSR to be able to cope with threat of German aggression and role of Czech and Slovak periodical press to inform public about dramatic political development during years 1935-1937. Attention is given to endeavors of periodical press in creation of confidence in Czechoslovak Republic ability to withstand danger of aggression from Nazi Germany.
\end{abstract}

\section{Keywords}

Nazi Germany, military buildup of Germany, reflection of events by periodicals, medial policy, Czechoslovak fortifications, Czechoslovak Army

\section{Introduction}

The aim of the paper is to trace Czechoslovak-German relations during years 1935-1937 as they were depicted in commentaries of Czech and Slovak periodicals. The factual description of events of a substantial significance, which were already elaborated in numerous periodicals and monographs, was described only in a concise fashion. The attention is given mainly to influence of newspapers upon formation of public awareness in regard to political changes in Europe, which could threated security of Czechoslovakia. Since establishment of Czechoslovakia periodicals were an important tool of shaping-up public opinion. Their significance increased during second half of thirties, in time when Nazi Germany was threatening very existence of the Republic. Therefore, government authorities devoted a great attention to content of articles published and were limiting publishing articles which would in any way instill defeatism in society. In that sense, namely 
role of press supporting ruling coalition of political parties was painting an optimistic picture of political situation.

Periodicals payed only scant attention to indications that support of Czechoslovak allies was gradually weakening. On the contrary, a majority of newspapers argued that allies, namely France, stayed firmly behind the Republic and therefore there was no need to be worried. In atmosphere of increasing danger posed by Nazi Germany, this was a difficult task, which gained significance. A vexing question, which by far is not completely answered by submitted paper, is to what extent press was successful in shaping-up self-confidence of broad public. The optimal approach to solve, at list partially, this conundrum, in our view was to include a sizeable amount of citations from periodicals representing political opinions of main periodicals.

Since its establishment, representatives of the Czechoslovak Republic (CSR) perceived revisionist ambitions of Hungary as the primary danger to territorial integrity of CSR. This attitude was deeply rooted in minds of Czechoslovak political representatives and Czech and Slovak patriots. However, in reality Hungary could hardly be a menace to Czechoslovakia. According to the Trianon Peace Treaty, Hungary had no right to build an army stronger than 30,000 men. In addition, the Hungarian army was prohibited to be armed with heavy weaponry, artillery and air force. On the contrary, Czechoslovakia, which was an industrial state, had one of the most advanced military forces in the Central Europe. Another factor in security of Czechoslovakia was the Treaty with France and the Alliance with Rumania and Yugoslavia, known as The Little Entente (Malá dohoda). The Little Entente was established to provide a mutual support of signatory states in case of military conflict with Hungary. As a result of these arrangements, CSR till second half of thirties, could feel reasonably well protected.

A placid state of political situation in the Central Europe ended after Adolf Hitler, the Chairman of the National Socialist German Worker's Party (Nazi Party), became the German Chancellor on 30 January 1933.

Similarly like Hungary, according to the Versailles Peace Treaty, Germany was obliged to limit its armed forces to 100,000 men. However, A. Hitler was determined to break, as he called, "shackles of Versailles". On 1 October 1934 he increased numerical size of the German Army to 300,000 men, which was a stark violation of the Versailles Peace Treaty.

On 13 January 1935, a plebiscite in the Saar region, which was temporarily placed under French control, was enacted. Inhabitants, who were overwhelmingly of German extraction, voted for return to Germany. České Slovo, an official periodical of the Czechoslovak the National Socialist Party, wrote that result of voting should be valued positively, because continued occupation of the Saar region by France could lead to conflict between France and Germany. Returning the Saar region to Germany allegedly liquidated a danger to peace in Europe. ${ }^{1}$ A. Hitler expressed his gratefulness to inhabitants of the Saar for their desire to be united with Germany and proclaimed that there will be no further territorial claims on part of Germany. Also French Prime Minister Pierre-Étienne Flandin, at least officially, declared satisfaction and expressed hope that all possible discrepancies between France

1 České slovo, 1935, Year 27, No. 13, 16 January. 
and Germany will be easily solved. ${ }^{2}$ Daily Venkov, a periodical of the Republican Party, reported that on 17 January 1935 the Council of the League of Nations decided that on 1 March 1935 the Saar region will be unified with Germany. ${ }^{3}$ However, not every resident of the Saar region was happy with results of plebiscite. A Slovak regional daily Slovenský Východ, repoted that approximately 8,000 persons fled to France. ${ }^{4}$

Hopes that after annexation of the Saar region Germany will pursue a peaceful foreign policy, proven to be futile. On 16 March 1935 German government adopted a law, according to which universal military service was implemented. It was another violation of the Versailles Peace Treaty. ${ }^{5}$ Great Britain, France and Italy criticized Germany during conference at Italian city of Stresa, on 11 April 1935.6 Bi-weekly Politika, a newspaper commenting upon domestic and foreign events, expressed opinion that main goal of conference at Stresa was enforce the status quo in the Central Europe. ${ }^{7}$ The member states of the League of Nations condemned Germany and a majority of members, including Czechoslovakia, adopted a resolution, in which denounced Germany's policy. Slovák denník, one of newspapers representing views of Republican Party in Slovakia wrote that, "This resolution is categorically disapproving implementation of general military service in Germany and this way violation of the Peace Agreement." ${ }^{8}$ Despite sternly worded disapproval voiced by members of the League of Nations, the European Powers abstained from any further action. This deepen scepticism of the Central European countries in ability of the League of Nations to protect peace in Europe.

France, which awoken to threat posed by Germany, signet the Treaty of Mutual Assistance with Soviet Union. As was expected, Czechoslovakia, a loyal ally of France, followed shortly after. The Treaty of Mutual Assistance between the Czechoslovak Republic and the Union of Soviet Socialistic Republics (the Treaty) was signed on 16 May 1935 and ratified on 16 June 1935. But, there was a glitch, which could have a negative impact upon security of CSR the Treaty included a condition, which bound the Soviet Union to fulfil its obligation toward Czechoslovakia only when CSR, in case of a hostile attack, would be helped by France. This way, if France for any reason abstained from helping Czechoslovakia, also the Soviet Union was not obliged to help CSR. ${ }^{9}$ Nevertheless, the Treaty evoked a positive reaction in Czechoslovakia, namely from representatives of left political spectrum. Even prominent non-communist publicists like Ferdinand Peroutka and writer Karel Čapek, praised Beneš,

2 České slovo, 1935, Year 27, No. 13, 16 January.

3 Venkov, 1935, Year 138, No. 15, 18 January.

4 Slovenský východ, 1935, Year 17, No. 19, 23 January.

5 With headline openly critical to Germany - "The enemy of peace throw away its mask", an official periodical of Slovak branch of the Social Democratic Party - Robotnícke noviny, informed, that "On Saturday afternoon (16 March 1935) Reich Minister of Propaganda invited foreign media representatives and announced that Germany is establishing a general military service". Robotnícke noviny, 1935, Year 35, No. 92, 19 March.

6 Slovak regional periodical Slovenský východ, informed that "Participants regretfully acknowledged violation of the Versailles Treaty and expressed their determination to oppose any violation of treaties which would endanger European peace." Slovenský východ, 1935, Year 16, No. 89, 16 April.

7 Politika, 1935, Year 5, No. 7, 15 April.

8 Slovenský denník, 1935, Year 18, No. 92, 18 April.

9 PRAŽÁKOVÁ, Irena (ed.): Dokumenty moderní doby, Praha 1978, 271-275. 
for pressing hesitant France toward closer relation with Soviet Union. ${ }^{10}$ A communist historian Jaroslav Cesar asserted that the Treaty was positively valued by a large segment of general public. ${ }^{11}$ Venkov, an official newspaper of Republican Party, wrote that it was a significant diplomatic achievement, which enhanced security of Czechoslovakia. Venkov valued the Treaty as a "positive factor", because it would be for Czech Communist Party hardly possible criticized Czechoslovak military built-up after Soviet government proclaimed that increase of strength of Czechoslovak armed forces is in interest of Soviet Union. ${ }^{12}$ Contrary to positive reaction of large segment of general public in CSR, the Treaty with Soviet Union brought a sharply negative reactions in neighbouring countries, especially in Germany. ${ }^{13}$ German government pronounced triple alliance of France, Soviet Union and Czechoslovakia as being incompatible with Locarno Treaties. ${ }^{14}$

Signing of French and Czechoslovak Alliances with Soviet Union gave Hitler excuse to carry over the most provocative violation of the Versailles Peace Treaty - an incursion into demilitarized zone in Rhineland. On 7 March 1936, a small unit of the German Army entered Rhineland, which served as a buffer zone, shielding France from German attack. Considering an overwhelming French military superiority, it was a daring act of aggression, bordering on irresponsibility and German soldiers were instructed to retreat immediately, if French Army would attack advancing units. ${ }^{15}$ Surprisingly, though France could easily expel miniscule German force, France remained passive. Even assurance expressed by President Beneš that France can count on Czechoslovak full and active support in repelling German incursion, France did not interferred. ${ }^{16}$ France abstained from military intervention, despite her right to attack German forces, if they enter demilitarized zone. French Ambassador

10 KLIMEK, Antonín: Velké dějiny zemí Koruny české. Svazek XIV. 1929-1938, Praha 2002, 298-299.

11 "Signing of Czechoslovak-Russian Treaty resulted in a significant turn-over of the whole concept of Czechoslovak foreign policy. This event evoked a great interest and became a topic of considerations of representatives of all political orientations. (...) Czechoslovak-Soviet Agreement was welcomed also by leadership of the Czechoslovak Army, because it was opening new possibilities to secure defense of the Republic." CESAR, Jaroslav: Mnichov 1938, Praha 1978, 14-15.

12 Venkov, 1935, Year 30, No. 75, 17 May.

13 According to A. Klimek "The Treaty aroused critical response from all neighbors of Czechoslovakia. Berlin added the Republic among enemy states, the propaganda of Goebbels asserted that CSR fell under command of Soviet Union and allegedly existed a secret addition to the Treaty, which allowed establishment of Soviet military bases on Czechoslovak territory. Warsaw characterized the Czechoslovak-Soviet Treaty as threat to Poland. Budapest spoke about "a threat of new Panslavism" and similarly as Vienna, blamed Prague for opening a doors of Bolshevism to Europe." KLIMEK, 297.

14 "Nazi government dispatched to all signatories of the Locarno Treaties a special memorandum in which declared that French-Soviet Treaty was irreconcilable with principles of diplomatic agreements concluded at Locarno. Therefore, Germany in its part in March 1936 terminated the Locarno Treaty." JOHN, Miloslav: Záŕi 1938. I. Díl, Přípravy nacistického Německa na přepadení Československa v roce 1938, Brno 1997, 29.

15 "Germans themselves were not sure what will be a reaction to their crass violation of the Versailles treaty. Three front battalions which were crossing bridges (...) had strict orders to immediately retreat if they encounter units of the French Army. Also German diplomats had prepared new notes placing all responsibility on excessive zeal of several officers, who shall for their quickness brought before court". JOHN. I. Díl, 224-225.

16 "President of the Republic dr. Edward Beneš adroitly and in a clear form assured already on 7 March 1936 French Ambassador Louis de Monicault, that Czechoslovak Republic will follow France, if arbitrary behavior of Nazis will result in disadvantage against Germany." STRAKA, Karel: Československá armáda, pilír obrany státu z let 1932-1939, Praha 2007, 48. 
in Germany, Francois Poncet described course of deliberation of French government, which resulted in decision, to abstain from military strike. ${ }^{17}$

With scathing criticism valuated French weakness E. Beneš: "Hitler (...) by occupation of left bank of Rhine (...) struck to the European peace one of the last and decisive blows. (...) We declared clearly to French ambassador in Prague, that we will follow France, if consequences from Hitler's deed will be enacted. (...) However, nothing happen. France committed the most fateful mistake, damaging Europe. (...) West democracies acted with inexplicable weakness, hesitancy and carefree recklessness." 18 However, it is necessary to note that French would most likely act more decisively if Great Britain would agree to support France against Germany. ${ }^{19}$ Great Britain, however, dodged promise of support and this, in judgement of military historian M. John, annulled determination of France to wage offensive war against Germany. ${ }^{20}$

French failure to stop German insurgency had fatal consequences. A. Hitler came to conclusion that French will do anything to avoid military conflict with Germany. However, despite danger posed to Czechoslovakia by German incursion, commentaries of government press characterized occupation Rhineland by German Army as having negligible impact upon security of Czechoslovakia and emphasized firmness of alliance with France. Also French political representatives on several occasions proclaimed friendship between both countries as lasting and unbreakable. Despite all this propaganda, which was aimed to assuage Czechoslovak public, it was clear that position of France as guarantor of peace weakend. As a consequence of French passivity, also British government grew sceptical about French determination to take a firm stand against Germany. ${ }^{21}$ France as reliable ally was in commentaries of periodical press to a large extent replaced by Soviet Union. Abounding were positive news depicting Soviet achievements, high pace of industrial build-up and namely excellence of the Soviet Army. E. Beneš himself characterized

17 F. A. Poncet wrote that "Government was accused of weakness. It was blamed that missed opportunity to strike blow to Nazism, which possibly could be its end. However, later came to light that there were seriously considered possibilities of military interference. (...) But general Gamelin was convinced that even limited military operation is connected with unpredictable danger and therefore it can't be enacted without general mobilization. Government refused such eventuality". PONCET, Francois, A.: Berlín 1931-1938. Vzpomínky diplomata, Praha $1947,243$.

18 BENEŠ, Edvard: Paměti. Od Mníchova k nové válce a k novému vítězství, Praha 1948, 21-22.

19 "The French Foreign Minister, Pierre Etienne Flandin, flew to London on 11 March and begged the British government to back France in a military counteraction in the Rhineland. His pleas were unavailing. Britain would not risk was even though Allied superiority over the Germans was overwhelming." SHIRER, William, L.: The Rise of fall of the Third Reich, New York 1960, 293.

20 "After occupation of Rhineland in year 1936. (...) Czechoslovak strategic situation acutely worsened. By seizure of demilitarized zone at Rhine the distance of French boundary line to Czechoslovak projection at city of Aš increased to $350 \mathrm{~km}$ and what was even more important, French Army must before unfolding offensive cross Rhine and proceed with this river behind its back." JOHN, Miloslav: Záŕi 1938 II. Díl, Možnosti obrany Československa, Brno 1997, 17.

21 Bořivoj Čelovský, with hint of irony, wrote that "French proclamations about solidarity sounded quite convincing - to Czechoslovak public. (...) But British Government did not trust to French preparedness to war. Even less trusted Germany to French determination. (...) Already at the end of year 1937 it was clear, that in case of finding itself in crisis, the key to solving situation holds Great Britain." ČELOVSKÝ, Bořivoj: Mnichovská dohoda, Tilia 1999, 61. 
mutual relations between both countries as positive and mutually loyal. ${ }^{22} \mathrm{He}$ expressed his desire to increase friendship with Soviet Union despite political differences of Soviet and Czechoslovak regimes. ${ }^{23}$ With clearly propagandistic aim was organized a journey of Czechoslovak press representatives to Soviet Union. Report from journey, published by Czechoslovak media, was devoted to introducing communist country as beehive of gigantic construction works and asserted that Soviet people were proud of their country. Soviet Union was described as a country where all citizens could enjoy a high standard of social justice. ${ }^{24}$

Warming-up of relations led to close cooperation between Czech and Soviet military. In April 1935, a delegation of Russian air force members arrived to Prague, officially with aim to become familiar with Czechoslovak industry. Venkov informed that, "Soviet visitors, in great detail were studying aircraft factory in Letňany. "25 Beneš wrote in his memoirs that build-up of friendly relations resulted in mutual visits of high military officials from both countries. ${ }^{26}$ After visiting Soviet Union, the Chief of the Czechoslovak General Staff Ludvík Krejči declared that "Russian representatives view Czechoslovakia as a friend and reliable ally in good and in bad times. "27 Friendly relations between Soviet and Czechoslovak government representatives, resulted in Beneš' journey to Moscow. Before his visit E. Beneš expressed hope that journey will become "a base for further cooperation in struggle for peace". ${ }^{28}$ After arrival to Moscow on 8 June 1935, Soviet leaders welcomed Beneš with almost a royal pomp. Soviet People's Commissar, Maxim Litvinov in his welcoming speech described E. Beneš as an exceptional warrior for peace and priced cooperation between both countries. ${ }^{29}$ Beneš was extremely pleased with flattery poured on him by Soviet leaders. In discussion with the British ambassador Joseph Addison, he summarized his impressions from Moscow visit in rosy colours. There was no a word of criticism in regard to oppressive nature of Soviet regime. Sceptical Briton discarded accolades expressed by Beneš and was openly critical in his report to London. Though couched in diplomatic

22 "Our cooperation with Soviet Union after conclusion of the Treaty from year 1935, was generally ordinary, steady and consequential. Politically we were in constant contact and loyal exchange of opinions in regard of general situation and certain coordination of policy on part of both sides was never broken." BENEŠ, 65.

23 According to A. Klimek, "Beneš during his journey to Soviet Union on 8 July 1935, where he was welcomed with highest pomp and honors, declared: "I came to Moscow so I can (...) even more reinforce our friendly mutual relation between our states and nations. (...) Despite difference of your regime (...) our state continuously pressed on unity with you in peaceful collaboration. (...) In this our foreign policy always saw its primary life interest." KLIMEK, 299.

24 České slovo, 1935, Year 27, No. 28, 30 January.

25 Venkov, 1935, Year 30, No. 20, 18 April.

26 E. Beneš wrote, that "Already on 30 May 1935 was undertaken, on the base of my consent, an official military delegation (...) which initiated first air force cooperation with Moscow. In August of the same year, a delegation of Soviet Army, led by general Šapošnikov, took part on our first great maneuvers, inspected our whole armament industry and prepared our later important arms shipment for Soviet Army." BENEŠ, 65.

27 Venkov, 1935, Year 30, No. 232, 5 October.

28 Robotnícke noviny, 1935, Year 32, No. 134, 9 June. Robotnícke noviny and České slovo published a number of articles, so thrilled about Soviet-Czechoslovak friendship, that their commentaries were frequently undistinguishable from reports written by communist newspapers.

29 LUKES, Igor: Czechoslovakia between Stalin and Hitler: the diplomacy of Edward Beneš in the 1930s, New York 1996, 53. 
language, it contained derogatory remarks in regard to ability of Beneš to perceive realistically the true nature of Soviet regime. ${ }^{30}$

Czechoslovak press, especially left oriented periodicals, celebrated Beneš' visit and exalted military excellence of the Red army. Venkov reported that Soviet Union is building a powerful army of 1.3 million men strong. Quality of Soviet military was allegedly continually increasing by young officer corps and air force personnel, who were entering service. These developments were assurance that any "air attack against Russia would be futile". ${ }^{31}$ In Slovakia, main source of admiring, but frequently imprecise or outride false commentaries, was communist periodical Slovenské zvesti. Paper argued that despite monstrous purges, which tragically affected thousands innocent victims, including officers of the Red Army, thanks technical innovations and new types of weapons the Red Army was still the best military organization in the whole world. ${ }^{32}$ Characteristic for slavish nature of Czechoslovak communist press, was unconditional agreement of condemnation of Marshal Mikhail Tukhachevsky by Soviet regime, who was one of the most gifted military strategists. Slovenské zvesti described M. Tukhachevsky as a traitor and informed about numerous public gatherings in Soviet Union, where participants were expressing their "unanimous agreement" with his execution. ${ }^{33}$

Openly pro-Soviet foreign policy pursued by E. Beneš aroused a wave of critical reactions abroad. Even France, which presented itself traditionally as staunch ally of Czechoslovakia, viewed growing admiration of Soviet Union by Czechoslovak Foreign Minister with suspicion. Unprecedented purges in Soviet Union, which unfolded during second half of thirties and decimated tens of thousands Soviet citizens, undermined opinion of French military leaders that fighting strength of Soviet armed forces can be maintained despite mass murders of officers. This scepticism led to conviction that French Army must concentrate on protection of its own country.

During the second half of thirties, cracks developed in the Little Entente. Romania, in face of rapid economic and military build-up in Germany, was increasingly viewing its alliance with Czechoslovakia as a burden. In case when dreaded military conflict between CSR and Germany was becoming possibility, Romanian leaders were not inclined to support Czechoslovakia. Even more openly than Romania, was reluctant to support Czechoslovak Republic Yugoslavia. Despite declarations of cordial relationship, differences between Yugoslavia and CSR grew deep. ${ }^{34}$ Yugoslav Prime Minister M. Stojadinović, during conference of the Little Entente enacted on 13 September 1936 in Bratislava, openly rejected any additional political commitments. Reluctance of Yugoslavia to broaden

30 lbidem, 56.

31 Venkov, 1937, Year 32, No, 14, 17 January.

32 Slovenské zvesti, 1937, Year 2, No. 39, 25 February.

33 Slovenské zvesti, 1937, Year 2, No. 114, 15 June.

34 "Though regular sessions of various panels of Little Entente were asserting "perfect harmony", which existed among constituent states, already in year 1936 was crisis inside of this "fifth European power" evident. Prince Pavel refused in June 1936 to reinforce Alliance and similarly Stojadinović refused suggestion made by Beneš to broaden Alliance as prevention against attack upon Czechoslovakia by Germany." ČELOVSKÝ, 66. 
obligations, admitted also E. Beneš in his Memoirs. ${ }^{35}$ According to K. Straka Rumania and Yugoslavia did not share Czechoslovak anti-German policy. ${ }^{36}$

But the most worrisome was deterioration of relations between Czechoslovakia and Germany. German propaganda, orchestrated by Josef Goebbels, was accusing Czechoslovakia of anti-German policy, of supressing minority rights of Sudeten Germans and offering political asylum to German emigrants. After usurpation of power in Germany by Nazi Party, mass purges of communists, social democrats and all left oriented persons who resisted Nazi regime ensued. ${ }^{37}$ Scores of these persons escaped to democratic European countries, including Czechoslovakia. German emigrants were receiving help from Czechoslovak left political parties and organizations, which aroused wrath of German official places. ${ }^{38}$

With aim to supress growing tensions with Germany, Czechoslovak government authorities curtailed anti-Nazi propaganda waged by German political emigration. Emigrants were also excluded from large cities and from frontier region in Western Czechoslovakia. But, because support of Czechoslovak leftist political organisations to German emigrants, this practice was eventually terminated.

Tensions between Germany and Czechoslovakia were further increased by policy of the Ministry of Interior, which tried to stop flow of German newspapers coming to Czechoslovakia. ${ }^{39}$ As a hostile act was judged by Germany prohibition of shipments and distribution of propagandistic materials and non-periodic press. ${ }^{40}$

Facing ominous situation, Czechoslovak government adopted during second half of third decade a number measures to increase military strength of CSR. Shortly after A. Hitler's coming to power, military service in Czechoslovakia was extended from fourteen months to two years.

35 Beneš wrote in his memoirs: "Far more serious was direct Yugoslavian refusal of cooperation against disintegration of Europe, coming from Germany. This expressed personally to me the Prime Minister of Yugoslavian government Milan Stojadinović, when on 12 September 1936 arrived at Topolčianky." BENEŠ, 49.

36 It became evident, that determined attitude of Czechoslovak Republic was not fully supported by the allies of the Little Entente. STRAKA, 48.

37 "In Czechoslovakia found asylum for shorter or longer time namely emigrants from middle ranks of society (merchants and clerks), freelance occupations (doctors, lawyers), intellectuals, artists and workers." ČERNÝ, Bohumil: Most k novému životu. Nemecká emigrace v ČSR v letech 1933-1939, Praha 1967, 15.

38 Historian Robert Kvaček wrote, that "Source of tensions was also an issue of German immigration to CSR. A substantial percentage was composed of communists, social democrats and also members of intelligentsia. (...) Government circles tried to limit residence of emigrants (Berlin ambassador Mastný declared at Wilhelmstrasse, that emigration is for his government an "unpleasant issue" and that "we surely have same interest with Germany against communism", however, communist, social democratic and some other organizations were securing for emigrants means for existence and even for political activity. And government authorities tolerated them." KVAČEK, Robert: Nad Evropou zataženo. Československo a Evropa 1933-1937, Praha, 1966, 36.

39 On 3 February 1934 the Ministry of Interior and the Ministry of Foreign Affairs issued a joint Decree No. 5143/1934-5, which prohibited distribution of cited periodicals on territory of CSR. Štátny archív Košice (State Archive Košice, hereinafter referred to only as SA K), fond Okresný úrad Rožňava (fund County Office Rožňava, hereinafter referred to only as OÚ Rožňava), carton 26, doc. No. 6500/34 prez.

40 For example, on 8 January 1934 the Ministry of Interior issued Decree No. 769/1934-5 prohibited distribution of non-periodic document "Adolf Hitler spricht - Ein Lexikon des Nationalsozializmus". SA Košice, f. OÚ R, carton 26, doc. No. 1816/34 prez. 
Encirclement of CSR by hostile states evoked worries perceived by a large segment of general public and enhanced importance of the Army. Chief of the General Staff, Ludvík Krejčí, formulated several conditions, which would increase fighting ability of military forces. Among others, he demanded implement measures which would increase on number of officers and implementation of two years of military service without time limitation. ${ }^{41}$ Strategy of Czechoslovak armed forces in event of German attack was based on supposition that France and the Little Entente will defend Czechoslovakia. ${ }^{42}$

Czechoslovak political leaders had a significant role in presenting army as indispensable element in security of the Republic. Instrumental importance in propaganda, which was aimed at increase of confidence of public in ability of the Army to protect state had newly elected president, E. Beneš. ${ }^{43}$ President reassured citizenry, that the Army is reliable guarantor of Czechoslovak security and each citizen can be sure that CSR is safe. ${ }^{44}$ Though in public speech in České Budejovice in May 1937 he admitted that there exist growing tensions in Europe and in other regions of the world and the League of Nations is incapable to interfere, he expressed conviction that all difficulties can be solved and there is no need to be worried and our cooperation with neighbours is continuing." 45

As was mentioned, already in year 1932 military service was prolonged from 14 months to two years. Personal changes were implemented on top army positions - Jan Syrový became the General Inspector of the Army and Ludvík Krejčí the Chief of General Staff. ${ }^{46}$ With the aim to increase security of boundary regions, the State Defensive Guard (SDG) was established in year 1936. In the event of outbreak of war, SDG should timely declare alarm and engage in defensive of attacked region. A task of SDG was also supress all forms of disturbances. During peace time SDG was subordinated to the Ministry of interior, in case of outbreak of war its superior organ become the Ministry of National Defensive. At the outset of 1936 were established so called the National Guards (NG), paramilitary organizations which were during mobilisation and in time of military conflict obliged to assist to regular army. The National Guards were dislocated in frontier regions. ${ }^{47}$

41 České slovo, 1935, Year 27, No. 17, 20 January.

42 "The General Staff of CS. Army, led by the Army General Ludvík Krejčí, already in autumn 1934 completed a strategic plan for defense of the Republic, which supposed that defensive units will have to carry on during two-three months (until start of military action by allies, that is France and states of the Little Entente - Romania and Yugoslavia) an isolated defense against superiority of Hitler's Germany and Horthy's Hungary. The goal of this plan was to prevent isolation of CS. Military units in Czech territory and to secure their transfer to Slovakia, where after regrouping of troops and arrival of allies should cs. Army engaged to counter offensive." ČAPLOVIČ, Miloslav: Československá armada a Slovensko, in: Slovensko v Československu, ZEMKO, Milan - BYSTRICKÝ, Valerián (eds.), Bratislava 2004, 262.

43 E. Beneš became President of CSR on 18 December 1935.

44 Slovak regional periodical Slovenský východ published address in which Beneš asked public not to believe that CSR will be attacked. Slovenský východ, 1936, Year 20, No. 192, 20 August. In similarly optimistic tone Benešs described status of German minority in rose colors and expressed conviction that relations between Czechs and Germans will be solved peacefully. České slovo, 1936, Year 28, No. 192, 20 August.

45 Ĺudový chýrnik, 1937, Year 12, No. 20, 16 May, 2.

46 KÁRNÍK, Zdeněk: České země v éře První republiky (1918-1938). Díl tretí. O přežití a o život (1936-1938), Praha 2003, 452.

47 JOHN, II. Díl, 155. 
Military preparations posed a significant burden upon state finances. According to M. John, the Ministry of National Defensive during years 1935-1937 demanded 6,740,405,000 crowns to finance increase of army units, modernization of weaponry and purchase of military materiel. However, till end of year 1937, only $30 \%$ of planned military build-up was realized. ${ }^{48}$

Politically difficult was planned substitution of cavalry units by mechanized troops. The Ministry of National Defensive was traditionally a domain of the Republican Party, which also controlled of the Ministry of Agriculture. A significant segment of agricultural economy constituted breeding of horses for military. Therefore, leaders of the Republican Party opposed elimination of cavalry units in the Czechoslovak Army. Political impasse was eventually solved by a compromise. Cavalry units were retained and increased was a number of tank units. ${ }^{49}$

With a goal to increase of fighting readiness of the Army, manoeuvers enacted at various localities of Czechoslovakia were undertaken. Czech and Slovak periodicals devoted extensive attention not only to actual course of military exercises, but also to description of high degree of tactical and strategic mastery of army, which should prove its ability to protect security of the Republic. ${ }^{50}$

A momentous decision, which foreordained strategy of Czechoslovak military buildup, was adoption of the French defensive model and consequently construction of line of bulwarks around almost whole Czechoslovak boundaries. ${ }^{51}$ Design of defensive works assumed concrete form during spring 1936. It was decided to construct two basic types of fortifications - heavy fortresses (HF) and light strongholds (LS). According to K. Straka, on the beginning of year 1937 already existed in Czech Land and in Slovakia several lines composed of hundreds light fortresses. However, the General Staff did not perceived light fortification as important segment of territorial defensive..$^{52}$ Primary importance in the system

48 JOHN, I. Díl, 30-31.

49 According to Z. Kárník: "This cardinal issue of reorganization of army was complicated by resistance of conservative segment of officer corps, also by government and the Republican Party." KÁRNíK, 470.

50 Periodical Venkov characterized series of manoeuvers initiated on 20 August 1936 in Czech part of CSR as "The largest form of all, till then, organized military exercises". According to Venkov, military, but also political and social importance of manoeuvers was enhanced by presence of President, Premier and Chairmen of both chambers of the National Assembly. In his public speech Beneš asserted that it was done everything to increase ability of army to fend-off hostile attack. He expressed his firm belief, that peace will be preserved: "By all this what I just said, I do not want to awake an impression in you that a war threatens. (...) According to my conviction and firm hope, Europe will succeed to preserve peace. (...) We with all our energy are working and will work to maintain peace." Venkov, 1936, Year 31, No. 194, 21 August. České slovo depicted military exercises, which were attended by hundred thousand soldiers, as celebration which deepen morale soldiers as well as civilians. České slovo, 1936, Year 28, No. 194, 21 August. Approximately year later, on 17 August 1937 also in SouthWestern Slovakia were executed manoeuvers, which employed military units adjusted to this region. Venkov, 1937, Year 31, No. 193, 17 August.

51 "The decision to build-up a complex system of fortified objects along the Czechoslovak border and defensive lines within the country was taken in the fall of 1934 and construction began early in the following year. (...) The whole project was divided into several phases, of which the fist was to be completed in 1942, the last in 1946." LUKES, 120.

52 "In regard to value of light fortification the General Staff had no illusions. Theses fortifications theoretically should be capable held enemy for limited time on the assumption that attack will be not supported by heavy weaponry." STRAKA, 78. 
of fortification had heavy fortresses, which were capable offer to defending personnel a long-lasting protection without support from outside. HF could withstand attack of heavy weaponry, but construction was complex, lasted long time and was substantially more expensive in comparison to light fortifications. ${ }^{53}$ Therefore, construction of fortifications placed an enormously heavy burden on state finances. ${ }^{54}$ The total cost was estimated at more than 10 billion Crowns. ${ }^{55}$ Despite strenuous effort of authorities to speed-up construction, at the close of November 1937, work was only partially accomplished. From total number of planned 1,276 HF, till 15 November 1937 was finished only 156 fortresses. Similarly, from 15,463 LS, only 3,268 strongholds were completed. . $^{66}$

Difficulties affected also process of supplying arms to the Army. Especially conflicting relations existed between the Ministry of National Defensive and corporation Škoda Works, which was a monopoly manufacturer of artillery. Škoda Works was far more interested to export less advanced artillery to customers in South America, than to fulfil requirements of MND for modern weapons. Export of advanced weapons to private customers, which would be profitable and cover expenses spent for research and production of new and advanced weapons, was restricted. Another problem, which led to conflicts between management of Škoda Works and government authorities, was reluctance of company to supply armament to Yugoslavia and Romania because these countries were slow payers. ${ }^{57}$ Therefore, management of companies producing weapons was reluctant to comply with military leadership. For example, requirement to implement multi-shift production was flatly refused. Also detrimental to supply of arms for the Army was interest of companies to maintain their export obligations. ${ }^{58}$

Czechoslovak Republic, besides Czechs and Slovaks, was composed of several ethnic minorities. Germans and Hungarians were most numerous and politically relevant. A majority of Germans and Hungarians became constituents of Czechoslovakia involuntarily. As was mentioned, potential danger to integrity of Czechoslovakia stemming from Hungary ambitions to occupy region of South Slovakia, where a majority of ethnic Hungarians lived, was effectively neutralized by the Little Entente, whose combined economic and military power was far greater than that of Hungary. Though political representatives of Hungarian minority parties were critical of allegedly insufficient minority rights, they enjoyed their

53 "HF, which demanded longer time to construct, could be build-up only at localities of the most strategic importance." JOHN, II. Díl, 236.

54 "Strategic plan of military defense of CSR required high financial expenses not only in relation to numerical number of the CSR Army and modernization of its armament, but also in build-up of continuous line of fortifications along almost whole 4,120 kilometers along Czechoslovak boundaries (of which only $201 \mathrm{~km}$ constituted boundary with friendly Romania. The plan of Czechoslovak fortifications, which was approved by the Army General L. Krejčí on 20 March 1935, was based on French experiences during construction of the Maginot Line and from his defensive doctrine, which supposed that existence of permanent and massive fortifications will stop attackers, enable enact mobilization and initiate counter offensive." ČAPLOVIČ, 263.

55 KÁRNÍK, 463.

56 Ibidem, 464.

57 "These unnatural relations led to frequent conflicts, which must be solved by dubious arrangements on individual basis and mostly were damaging export as well as interest of the Army." JOHN, II. Díl, $172-173$.

58 "Urgent needs of defense of the Republic collided with export interest of weapon producers. Orders placed by foreign customers covered from one third up to half of production capacity of manufacturers." STRAKA, 67. 
legal status and actively participated on political life in the CSR. Similarly, members of German community enjoyed political rights and established a number of political parties. Though the relations between Czechs and Germans were never ideal, coexistence was peaceful. This, however, changed after A. Hitler's ascent to power in Germany. Chauvinistic frenzy engulfed a majority of Sudeten Germans and grew into hatred between Czechs and Germans. This rift was exacerbated by a policy of Nazi Germany, using German minority as a tool of its aggressive aims. Therefore, political and military representatives must take into consideration that inclusion of large numbers of German and Hungarian conscripts will have a negative impact on loyalty of the Czechoslovak Army. ${ }^{59}$ Security authorities must face potential hostilities on part of Germans and Hungarians. With the aim to prevent leaking sensitive information, the Ministry of Interior issued promulgation which informed press what constitute subject-matter of prohibited news. Primarily targeted were information dealing with military issues, such as construction of defences, description of manoeuvers, localities where military units were situated etc. Because it was impossible in detail define all types of information, which could be inimical to security of state, in case when authority empowered by control of press were not sure which concrete bit of information is not allowed to be published, were obliged to request decision by the Ministry of Interior or the Ministry of National Defense. .00

Growing danger that Czechoslovakia could become a target of hostile attack, initiated measures focused upon preparation of civilian population on defense. The main task to enact these preparations was in competence of institutions of compulsory education. During years 1934 and 1935 the School Administration issued ordinance in regard to defense education, which was obligatory to pupils of elementary schools and high schools students. ${ }^{61}$ Important measure initiated by government, which intendent engage civilian population into defensive activity was establishment of so called the National Defense Education (NDE). ${ }^{62}$ According to cited Law No. 184 - the Law in Regard to Defense of State, the aim of the NDE was "Nurture in population of Czechoslovak Republic, in dependence to its age, to acquire professional, moral qualities, physical endurance, knowledge and skills, which are needed to defense of state ( $\S 1$ of Law in Regard to Defense of State)." Czechoslovak citizens of both genders were obliged to participate on NDE. If it was no in breach of international agreements, cited obligation was mandatory also for foreigners who had permanent residence in CSR. As compulsory topic was National Defense Education implemented to all types of schools. Via several government measures

59 John, M. wrote that: "Presence more than $25 \%$ of Sudeten German soldiers in the Czechoslovak Army constituted a considerable danger. It was doubtful that they will fight for Czechoslovak state against soldiers with whom they were connected by same language." Therefore, "Czechoslovak military administration incorporated Sudeten German conscripts into positions in which they could not have large impact upon development of fighting situation, to non-combatant forces in Slovakia, to transport forces and to a large extent to artillery and to engineer corps." JOHN, II. Díl, 182.

60 SA Banská Bystrica, branch (b.) Rimavská Sobota, fond Okresný úrad Rimavská Sobota 1938, carton 19 Nedovolené spravodajstvo - vyhláška, ktorou sa prevádza ustanovenie § 23, č. 1, odst. 1 zákona na ochranu republiky.

61 ČAPLOVIČ, Miloslav: Branné organizácie v Československu 1918-1939 (so zretelom na Slovensko), Bratislava 2001, 62.

62 Sbírka zákonů a nařízení státu československého. Částka 45. Vydána dne 15. července 1937. 184, Zákon ze dne 1. července 1937 o branné výchově. 
implemented during years 1935-1937 was set-up so called the Civil Air Defense. On 15 April 1937 the Ministry of Interior issued Guidance for training civil air defense. The goal of training was to test readiness of executive authorities, gain experience in preparations for air defense and to assure population that public security is safeguarded. ${ }^{63}$ Magnitude of defensive measures, which accelerated in dependence on worsening political situation in Europe, demanded constantly increasing amount of finances. To provide needed money, on 26 May 1936 government representatives submitted to the National Assembly a draft bill to issue the Loan on Defense of State. ${ }^{64}$ Necessity to raise additional funds to cover defense expenses was generally accepted. Even Slovák - an official periodical of opposition Hlinka's Slovak Peoples Party (HSPP), acknowledged justification of the loan: "It is necessary to admit, that state unconditionally needs a fairly trained army and all defensive means of modern age, because insufficient armament could be very costly. ${ }^{165}$ However, members of the National Assembly representing HSPP abstained during voting and left Parliament. Also members of the National Assembly representing the Czechoslovak Communist Party abstained from voting. Communist periodical Slovenské zvesti justified refusal to vote by argument the cited Law is favoring rich at the expense of ordinary citizens. ${ }^{66}$ The Loan on Defense of State (the Loan) was approved on 27 May 1936 by a large majority of deputies. According to České slovo voting was "a great manifestation of firmness of the Republic and acknowledgment of its strength and unshakable existence." ${ }^{67}$ During following months Czechoslovak press presented the Loan as great success and gesture of staunch patriotism on part of citizens. ${ }^{68}$

As threat posed by Germany during period years 1934-1937 was gradually increasing, it became necessary to mobilize al human and economic resources to prepare for defense of the Republic. Unfortunately, mainly due to failure of allied states to stay firm by Czechoslovakia, A. Hitler succeeded in destruction CSR.

\section{Conclusion}

The aim of the submitted paper is map commentaries of Czech and Slovak periodicals tracing the political development of Czechoslovak Republic during years 1935-1937, which was a period of growing instability in Central Europe resulting from aggressive policy of $\mathrm{Nazi}$ Germany. Attention was also given to measures enacted by political leadership and military as informed by press and to endeavors of newspapers to create an atmosphere of optimism

63 Smernice pre cvičenie civilnej protileteckej ochrany (CPO). Vydané výnosom ministerstva vnútra zo dňa 15. apríla 1937 č. 21.705/14. (Directives for anti-aircraft excecises dated 15 April 1937, No. 21.705/14. Issued by Decree of the Ministry of Interior on 15 April 1937, No. 21.705/14).

64 Venkov, 1936, Year 27, No. 123, 26 May.

65 Slovák, 1936, Year 18, No. 122, 27 May.

66 Slovenské zvesti, 1936, Year 1, No. 10, 29 May.

67 České slovo, 1936, Year 28, No. 125, 28 May.

68 České slovo cited radio-speech made by President Beneš in which he expressed opinion that the Loan is primarily "the moral imperative". České slovo, 1936, Year 28, No. 131, 5 June. Venkov emphasized necessity to provide all means for defense of state and purpose of the Loan is secure financial cover to do it. Venkov, 1936, Year 27, No. 159, 10 July. Slovenský východ published interview of Prime Minister Milan Hodža in which he characterized results of the Loan as great success and proof of patriotism of Czechoslovak citizenry. 
face to face to German threat. This was helped by repeated proclamations declared by France leaders about determination of France to stay firmly by Czechoslovakia. Another development judged by periodicals highly positively was signing defensive alliance with France and Soviet Union. Noticeable was political shift to left as a consequence of buildup friendly relations with Soviet Union. Especially left oriented periodicals were publishing eulogies glorifying strength of Soviet Army. Press paid extensive attention to government firm support strengthening of military and to construction of defensive works. Analysis of articles published in a majority of periodicals points to fact, that press was an efficient tool in creating an atmosphere of optimism, that the Republic will withstand possible German aggression.

\section{References}

Štátny archív Košice (State Archive Košice), fond Okresný úrad Rožňava (fund County Office Rožňava)

- carton 26, doc. No. 6500/34 prez.

- carton 26, doc. No. 1816/34 prez.

SA Banská Bystrica, branch (b.) Rimavská Sobota, fond Okresný úrad Rimavská Sobota 1938 (fund County Office Rimavská Sobota), carton 19.

České slovo, 1935, Year 27.

České slovo, 1936, Year 28.

Politika, 1935, Year 5.

Robotnícke noviny, 1935, Year 32.

Robotnícke noviny, 1935, Year 35.

Slovák, 1936, Year 18.

Slovenský denník, 1935, Year 18.

Slovenský východ, 1935, Year 16.

Slovenský východ, 1935, Year 17.

Slovenský východ, 1936, Year 20.

Slovenské zvesti, 1936, Year 1.

Slovenské zvesti, 1937, Year 2. 
Venkov, 1935, Year 30.

Venkov, 1936, Year 27.

Venkov, 1936, Year 31.

Venkov, 1937, Year 31.

Venkov, 1937, Year 32.

Ĺudový chýrnik, 1937, Year 12.

BENEŠ, Edvard: Paměti. Od Mníchova k nové válce a k novému vítězství, Praha 1948.

CESAR, Jaroslav: Mnichov 1938, Praha 1978.

ČAPLOVIČ, Miloslav: Branné organizácie v Československu 1918-1939 (so zretelom na Slovensko), Bratislava 2001.

ČAPLOVIČ, Miloslav: Československá armada a Slovensko, in: Slovensko v Československu, ZEMKO, Milan - BYSTRICKÝ, Valerián (eds.), Bratislava 2004, 262.

ČELOVSKÝ, Bořivoj: Mnichovská dohoda, Tilia 1999.

ČERNÝ, Bohumil: Most k novému životu. Nemecká emigrace v ČSR v letech 1933-1939, Praha 1967.

JOHN, Miloslav: Záři 1938. I. Díl, Přípravy nacistického Německa na přepadení Československa v roce 1938, Brno 1997.

JOHN, Miloslav: Záři 1938. II. Díl, Možnosti obrany Československa, Brno 1997.

KÁRNÍK, Zdeněk: České země v éře První republiky (1918-1938). Díl třetí. O přežití a o život (1936-1938), Praha 2003.

KLIMEK, Antonín: Velké dějiny zemí Koruny české. Svazek XIV. 1929-1938, Praha 2002.

KVAČEK, Robert: Nad Evropou zataženo. Československo a Evropa 1933-1937, Praha, 1966.

LUKES, Igor: Czechoslovakia between Stalin and Hitler: the diplomacy of Edward Beneš in the 1930s, New York 1996.

PONCET, Francois, A.: Berlín 1931-1938. Vzpomínky diplomata, Praha 1947. 
PRAŽÁKOVÁ, Irena (ed.): Dokumenty moderní doby, Praha 1978.

Sbírka zákonů a nařizení státu československého. Částka 45. Vydána dne 15. července 1937. 184, Zákon ze dne 1. července 1937 o branné výchově.

SHIRER, William, L.: The Rise of fall of the Third Reich, New York 1960.

Smernice pre cvičenie civilnej protileteckej ochrany (CPO). Vydané výnosom ministerstva vnútra zo dňa 15. apríla 1937 č. 21.705/14. (Directives for anti-aircraft excecises dated 15 April 1937, No. 21.705/14. Issued by Decree of the Ministry of Interior on 15 April 1937, No. 21.705/14.).

STRAKA, Karel: Československá armáda, pilî̌ obrany státu z let 1932-1939, Praha 2007.

\section{Author}

doc. PhDr. Soňa Gabzdilová, CSc.

Centrum spoločenských a psychologických vied SAV, Spoločenskovedný ústav Centre of Social and Psychological Sciences, SAS, The Institute of Social Sciences Karpatská 5, 04001 Košice, Slovak Republic sona.gabzdilova@gmail.com

doc. Mgr. Milan Olejník, PhD.

Centrum spoločenských a psychologických vied SAV, Spoločenskovedný ústav Centre of Social and Psychological Sciences, SAS, The Institute of Social Sciences Karpatská 5, 04001 Košice, Slovak Republic olejnik@saske.sk 